\title{
Egyenlőtlen fejlődés és felzárkózás
}

\section{The problem of uneven development and catching-up}

\author{
ARTNER ANNAMÁRIA
}

\begin{abstract}
ARTNER Annamária: tudományos főmunkatárs, MTA Közgazdaság- és Regionális Tudományi Kutatóközpont, Világgazdasági Intézet; 1112 Budapest, Budaörsi út 45.; föiskolai tanár, Zsigmond Király Egyetem; 1039 Budapest, Kelta u. 2.; artner.annamaria@krtk.mta.hu
\end{abstract}

\begin{abstract}
Annamária ARTNER: senior research fellow, Institute of World Economics, Centre for Economic and Regional Studies, Hungarian Academy of Sciences; Budaörsi út 45., H-1112 Budapest, Hungary; college professor, King Sigismund University; Kelta u 2., H-1039 Budapest, Hungary; artner.annamaria@krtk.mta.hu
\end{abstract}

Tervszerű gazdálkodás esetén az egyes ágazatok, funkciók, alrendszerek növekedése/fejlödése szükségképpen a vele kapcsolatos ágazatok, funkciók alrendszerek megfelelő fejlődését/változását hozza, ezért az egyenlőtlen fejlődés fogalma tervszerü társadalmi rendszerekkel összefüggésben nem értelmezhető. Az egyenlőtlen fejlődés az anarchikus termelőmódok attribútuma, s mivel minden eddig ismert termelőmód közül a kapitalizmus a leganarchikusabb, ezt jellemzi leginkább.

Az egyenlőtlen fejlődés fogalma Marxtól származik, és legáltalánosabban a fejlődés, átalakulás általános feltételét jelenti: a leszálló ágban lévő termelőmód átadja helyét a nála gyorsabb fejlődésre képes újnak. De egyenlőtlen fejlődésnek nevezte Marx a tőkés gazdaság „rendjét”, nevezetesen a szektorok, régiók eltérő ütemű fejlődését is, valamint a kapitalizmus fö ellentmondását, a gazdagság és tőke halmozódását egyfelől, a (relatív és abszolút) szegénység és kiszolgáltatottság növekedését másfelől. Összességében egyenlőtlen fejlődés jellemzi a világgazdaságot, annak minden regionális és strukturális vonatkozását, minden szinten, a helyitől a globálisig. Ezek az immanens ellenmondások adják a rendszer dinamikáját, hajtják fejlődését, változását.

Az egyenlőtlen fejlődés kérdése különösen hangsúlyosan jelent meg a második világháború utáni évtizedekben a fejlődő országok problémáit vizsgáló tanulmányokban, illetve az ezek tapasztalatait is ötvöző, Immanuel Wallerstein (2010) által egységbe fogott világrendszer-elméletben. A tőkés újratermelési mód neoliberális menedzselésének elterjedését hozó globalizációval az egyenlőtlen fejlődés minden dimenziója kiélezettebbé vált, úgy a jövedelmek, a vagyonok, a tőkeellátottság, mint a versenyképesség, a technológia és az intéz-

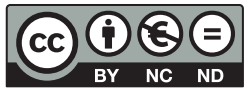


mények terén. Az egyenlőtlenségek át- meg átszelik a világgazdaságot földrajzi és strukturális dimenziókban egyaránt: az országokon belüli régiók, a nemzetek és a több országot magukban foglaló régiók viszonylatában éppúgy, mint a tőke és munka között, valamint a tőkén és munkán belül is.

A ma uralkodó neoklasszikus közgazdasági elmélet szerint a piaci szabadság lehetővé teszi bármely egyén, vállalat vagy ország feljebb lépését a fejlettségi létrán. A gyakorlat azonban ezzel ellentétes képet fest. Úgy tünik, a globális hierarchia a transznacionális vállalatok termelési hálózatainak és értékláncainak köszönhetően mára olyan mértékben megrögzötté vált, hogy az egyenlőtlen fejlődés csak kivételes esetekben eredményez utolérést, felzárkózást. Az alábbiakban ezt a kérdéskört járom körül.

Mindenekelőtt néhány fogalmi definíció. Egyenlőtlenségen mennyiségek nem egyenlő eloszlását értem. A fejlődés minőségi változást jelent. Ugyanakkor a minőség is mennyiségekkel határozható meg. Ebből az következik, hogy a fejlődés leírható mennyiségek változásával - a minőségi javuláshoz kívánatos mennyiségi csökkenés (például a szén-dioxid-kibocsátás esetén) leírható negatív növekedésként.

Az egyenlő fejlődés hierarchikus rendszerben megrögzíti a mennyiségek viszonyát és a növekedési ütem mértékében növeli abszolút különbségüket. Ha „A” ország GDP-je kétszerese „B” ország GDP-jének és mindkét ország GDP-je 5\%-kal nő, akkor ugyan nem változik a két GDP viszonya, viszont 5\%-kal nő a két GDP közti abszolút különbség, vagyis „B” ország messzebb kerül „A” országtól, mint volt.

Első konklúziónk tehát az, hogy az egyenlo fejlödés egy hierarchikus rendszerben az egyenlötlenséget erösíti.

A két mennyiség abszolút különbsége csak akkor csökkenhet, ha a kisebb mennyiség nagyobb ütemben nö, mint a nagyobb. Hogy mennyivel kell nagyobbnak lennie, azt a két mennyiség eredeti aránya mondja meg. Ha a növekedési ütemek aránya megegyezik a két mennyiség kiinduló arányával, akkor a köztük lévő különbség abszolút értéke változatlan marad. A különbség csak akkor csökken, ha a kisebb mennyiség növekedési üteme nagyobb arányban haladja meg a nagyobb mennyiség növekedési rátáját, mint amennyivel a nagyobb mennyiség meghaladja a kisebb mennyiséget. Az előbbi példánknál maradva: ha „A” ország GDP-je 100, „B”-országé 50 és „A” növekedési üteme $5 \%$ „B” országé pedig 10\%, akkor „A” ország GDP-je 105 lesz, „B” országé 55, így a köztük lévő különbség 50 marad. A különbség csak akkor és annyival csökken, amikor és amennyivel „B” ország növekedése meghaladja a $2 \times 5$, vagyis $10 \%$-ot. A felzárkózás feltétele tehát, hogy a fentiekben meghatározott növekedési ütem tartósan fennálljon, s bár a folyamat természeténél fogva, a felzárkózás előrehaladásával a növekedési ütem csökkenhet, ez hosszú éveken keresztül tartó magas növekedési ütemet jelent, s minél elmaradottabb országról van szó, annál magasabbat.

A magas növekedési ütem fenntartásához azonban belső felhalmozásra van szükség, miközben az elmaradottság jellemzője tipikusan a forráshiány. Ez 
utóbbi miatt külső források bevonására, valamint jelentős újraelosztásra van szükség. A külső források bevonásának szükségletéből ered a birodalomépítés (hódítás, rablás, integráció) történelmi törekvése a föld, a nyersanyag és a munkaerő feletti rendelkezés megszerzése végett, továbbá az eladósodásra, illetve a külföldi működő tőke bevonására való hajlam. Mind az eladósodás, mind a működőtőke-import azonban kevéssé oldja meg a forráshiány problémáját, sőt a velük járó forráskivonás (kamatfizetés, profitrepatriálás), illetve a külföldi működő tőke esetében az illékonyság miatt végső soron maguk is jelentősen súlyosbítják azt. Az újraelosztás pedig erős államot feltételez, amely a fizetőképes kereslet megteremtése és a struktúrapolitika végett képes az erőforrások megfelelő, a felzárkózást szolgáló átcsoportosítására.

Ebből adódik második konklúziónk, miszerint a felzárkózásnak meghatározott feltételei vannak, s ezek alapja a belső felhalmozás.

A belső felhalmozás s így a felzárkózás lehetőségei történelmileg változóak. 1990 előtt, a kapitalizmussal szembeni rendszeralternatíva bukását és a globalizáció kibontakozását megelőzően a nemzetállamok ereje, viszonylagos zártsága, fogyatkozó, de még észlelhető protekcionizmusa lehetővé tette a belső felhalmozást a gyengébb nemzetgazdaságok számára. Példa erre Japán, Délkelet-Ázsia újonnan iparosodó országai (jelentős amerikai segédlettel, különösen Dél-Korea esetében), valamint a kelet-európai „szocialista” országok pályája. Az 1990-es évek óta egyeduralkodó neoliberális világrendszerben azonban a nemzeti és nemzetközi folyamatok soha nem látott mértékben fonódnak össze, a felzárkózás megnehezült. A belső felhalmozásra ott van lehetőség, ahol a nemzetállam ereje még megmaradt. Ezt a politikai berendezkedés és/vagy a belső piac mérete biztosíthatja. Példaként Észak-Korea és a BRICS-országok hozhatók. Ezeket az országokat (még) nem tudta teljes egészében integrálni az USA-EU tengely által meghatározott globális tőkerendszer. Ugyanakkor azok az országok, amelyek „sikeresen” integrálódtak a hierarchikus tőkerendszerbe (fél-)perifériaként, a globális tőkemegtérülési ciklusok részeivé váltak, s így a bennük folyó „belső” tőkefelhalmozást a transznacionális tőke vezérli és csapolja le. Például az Európai Unió 11 középés kelet-európai tagországából 2002 és 2013 között a GDP 2,8\%-ával felérő profitot repatriáltak a multik, az időszak folyamán egyre növekvő mértékben: 2004-ig kevesebb, mint 2\%-ot, 2013-ban már 3,3\%-ot (lásd Hunya 2011 és 2014 adatait).

A transznacionális vállalatok értékláncaikon keresztül a világkereskedelem 80\%-át ellenőrzik. A vállalaton belüli transzferárak révén lehetőségük van „láthatatlanul” is értékeket kivonni a telephelyországokból. 2011-ben a transznacionális vállalatok 1500 milliárd dollárnyi jövedelemre tettek szert, amely 21000 milliárd dolláros tőkeállományukra vetítve 7\%-os profitrátát jelent. A fejlett országokban 5 , a fejlődő országokban azonban 8, az átalakuló gazdaságokban pedig 13\%-os volt a profitrátájuk. A nyereség kétharmadát (1 000 milliárd dollárt) kivonták a telephelyországokból (repatriálták vagy harmadik országokban fektették be). A fogadó országban hagyott profitrészt csak részben fektették be újra (UNCTAD 2013, ix-X., xiv-Xv.). 
A centrum a profitrepatriálás, a transzferárak és a cserearányok révén, valamint az elavult technológiáknak az alacsony bérü perifériákra telepítésével is extra erőforrásokra tesz szert, miközben állandósítja a (fél-)perifériák technológiai lépéshátrányát.

Mindez azt illusztrálja, hogy a félperifériákon és perifériákon a felhalmozás lehetősége növekvő mértékben korlátozott.

A globális kapitalizmusban a felzárkózási kísérletek a rendszerszintü mechanizmusok miatt eleve halálra ítéltettek, mondhatni önmaguk sírásóivá válnak. A „felzárkózási csapda” jelensége a perifériák függo” helyzetéből adódik és a következőképpen írható le. A külső forrásbevonás kényszere exportkényszert von maga után, hiszen a külső forrást (árut, hitelt, tőkét) ellentételezni kell, még mielőtt a felzárkózás megtörténne. Az erőltetett export azonban a termelési struktúra konzerválódását eredményezi, ez pedig a versenyképesség romlását, a külső egyensúly felborulását. Hasonló hatással jár az állami újraelosztás és termelésösztönzés, mivel a forráshiány okán ez többnyire költségvetési hiányhoz, majd hitelfelvételhez, vagyis belső és külső egyensúlyromláshoz vezet. Az ilyen „praktikákkal” nem próbálkozó, a globális tőkerendszerbe integrálódó periféria pedig, mint fentebb láttuk, ab ovo forráskivonást szenved el, az utolérés tehát számára is csak illúzió maradhat.

Harmadik konklúziónk, hogy a globalizációban az egyenlötlen fejlődés a centrum javára fordul - a fejlettek elönyét növeli. A periférián folyó termelésból származó profit a centrum tókefelhalmozását táplálja. A globális tókerendszerbe integrált perifériának nincs lehetösége a felhalmozásra/utolérésre.

Kérdés, feloldható-e a felzárkózási csapda. A totális árutermelés alapján, vagyis a globális kapitalizmus keretein belül nyilvánvalóan nem. Az egyedül kínálkozó megoldás a globális tőkerendszerről való leszakadás, az értékelvonási csatornák lezárása, az önellátás és lokalitás előtérbe helyezése, az egyenlőtlen fejlődést tápláló termelési anarchiát kiküszöbölő tervszerüség, valamint az együttmüködés a hasonló pályát választó országokkal, legelsősorban a tudományos eredmények megosztásában. Ezek azok a feltételek, amelyek a belső felhalmozás biztosításával megnyitják az utat a fejlődés, illetve a felzárkózás előtt.

A neoliberalizmusnak a gyakorlatban és az elméletben, a tankönyvekben és a médiában az elmúlt évtizedekben megszilárdult hatalma közepette bizonyára furcsán, sőt talán megbotránkoztatóan hat az önellátásra törekvésnek ez a pozitív színben való feltüntetése, pedig egyáltalán nem valamiféle légből kapott képtelenségről van szó. A világgazdaság kialakulását végigkíséri a szabad kereskedelem és a protekcionizmus harca, s aligha található ország, amelyik valamikor a történelme során ne alkalmazott volna nyílt vagy bújtatott protekcionista eszközöket. Sőt még a neoliberalizmus mai Grál-lovagjai sem mentesek ezektől, gondoljunk az EU vagy az USA agrárprotekcionizmusára, vagy az USA bevándorláspolitikájára. A helyi termelés sok esetben - így például az élelmiszereket illetően - sokkal egészségesebb és ezért végső soron olcsóbb, mint a messziről jött import. Csak figyelembe kell venni a kényszeréréssel járó szállí- 
tási időt, a szállítási költségeket és a vele járó környezetszennyezést, a helyi foglalkoztatás növekedéséből származó sokirányú előnyöket, nem utolsósorban a lakosság termeléstechnikai műveltségének s ezáltal innovációs képességének növekedését, nem beszélve a település vagy ország vonzerejének, népességmegtartó képességének erősödéséről - hogy csak egy pár szempontot említsek. Emlékeztetek rá, hogy a szabad kereskedelem mindenhatóságára épülő elmélet a korai kapitalizmus vezető hatalmának számító Angliában (illetve a vele egyesült Skóciában) született meg Smith, majd - és leginkább - Ricardo jóvoltából, az akkori haladás éllovasának, a feltörekvő ipari burzsoáziának az érdekeit fejezve ki. Sem a klasszikus elmélet, sem az erre épülő marginalista forradalomból születő mai föáramú elmélet nem érinti az egyenlőtlen fejlődés és a fejlesztés kérdéskörét. E problémák elméletbe emelésére és gyakorlati megoldására Keynes tett kísérletet, de újraelosztó gazdaságpolitikája csak az alternatív rendszerrel (a kelet-európai „szocialista” országokkal való) versengés gazdasági válságtól mentes évtizedeiben volt elfogadható a tőke számára.

A szabadjára engedett felhalmozás azonban olyan fokra hajtja az egyenlőtlenségeket a gazdaságokon, társadalmakon belül és országok, régiók között, amely egy kaotikus állapoton keresztül szétfeszíti a rendszert. Napjainkban ennek már számos fenyegető jele látható, sőt érezhető. Az egyenlőtlen fejlődés gyökereiről, hatásairól és lehetséges gyógymódjairól folyó gondolkodás tehát nem ismerhet tabukat.

\section{Irodalom}

Hunya, G. (2011): Diverging patterns of FDI recovery. WIIW database on foreign direct investment in Central, East and Southeast Europe. Wiener Institut für Internationale Wirtschaftsvergleiche, Wien

Hunya, G. (2014): Hit by deleveraging. WIIW database on foreign direct Investment in Central, East and Southeast Europe. Wiener Institut für Internationale Wirtschaftsvergleiche, Wien

UNCTAD (2013): World investment report. UN, New York, Geneva http://unctad.org/en/ PublicationsLibrary/wir2013_en.pdf (Letöltés: 2016. július 5.)

Wallerstein, I. (2010): Bevezetés a világrendszer-elméletbe. L'Harmattan, Eszmélet Alapítvány, Budapest 